Alex. v. Homeyer: Pratincola rubetra als Spottvogel. 295

ihrem Kropf Anethium graveolens, Chenopodium? und Carastium vulgare. Letztere Pflanze wächst massenhaft in den Dünen und wurde der Same mit der Schote verschluckt. Auch scharren die Fausthühner die kaum gesäeten Buchweizen gern aus, doch er. laubt ihnen die Kürze der Nägel nicht, die tiefliegenden Körner zu erreichen. Ihr Fleisch ist braun, trocken und von keiner besonderen Delicatesse.

Emden, 3. Juli 1865.

Pratincola rubetra als Spottvogel.

Ich glaube einen Anthus arboreus zu hören, der auf einem Baume sitzt und in bekannter Weise singt. Näher gekommen, erkenne ich im Sänger einen braunkehligen Wiesenschmätzer, der nur acht Schritt von mir entfernt ist; ich sehe, wie der Vogel singt, es ist keine Täuschung möglich, es ist ein interessanter Fall, denn die Pieperstrophen werden täuschend mit der diesem Sänger eigenen Sanftmuth und Milde wiedergegeben. Gleich darau före ich ein leises Schnurren, - ein Schnarren, und nun folgt der reine Naturgesang der $P$. rubetra. Kaum habe ich mich von meiner Ueberraschung erholt, da entquellen der kleinen Sängerbrust die bekannten, vollen, wohlthuenden Töne der Heidelerche (Alauda arborea), das Duidle, duidle, doch das Tempo wird schneller, aus dem runden Duidle wird ein oft wiederholtes rasches Didel, didel, endlich ein Diddiddiddiddid, woran ein Nachschlag. sich bildet. Noch ist das Ganze nicht recht erkenubar, doch eine drei- bis viermalige Wiederholung lassen den Schlag anders erscheinen; endlich ist er vollkommen geformt, es ist ein herrlicher sanfter und doch ziemlich starker Finkenschlag ( $F r$. coelebs), ein Reitzug. Der Vogel wiederholt ihn mehrere Mal, dann fliegt er auf eine Strauchpflanze und nimmt Nahrung auf, mit dem Gesange ist es vorbei, ich aber sehe ihm lange sinnend und stannend nach, denn eine solche Kehlfertigkeit hatte ich nie bei einem Vogel, am allerwenigsten aber bei einem Wiesenschmätzer beobachtet.

Ich habe den Vogel nie wieder gehört. Lange (nämlich schon seit dem 14. Mai 1860 in Rastatt) ist dieses kleine Evenement in meinem Tagebuche verzeichnet, - ich hielt es nie recht des Publicirens werth, doch immer, wenn die Notiz mir vor Augen $\mathrm{kam}$, interessirte sie mich ausserordentlich, und deshalb mag jetzt dem kleinen Musikus hierdurch ein bleibendes Andenken werden.

Glogau, den 18. Juli 1865.4 Alexander von Homeyer.

\title{
Nachrichten.
}

\section{Bitte an einen Leser des Journals.}

In der Zeitschrift "Aus der Natur" findet sich im 30. Bande oder neue Folge 18. Band p. $670-71$ ein Aufsatz über das Steppentuhn (ohne Namens- 


\section{A. v. Homeyer: Bitte. - Eingegangene Schriften.}

unterschrift), welcher am Schlusse meine in Dresdener zoologischen Garten gemachten und bereits im Journal fïr Ornithologie (XIr. p. 312) publicirten Beobachtungen über das Seelenleben nnd systematische Placirung unseres Vogels "wörtlich" wiedergiebt, ohne dass dabei mein Name genannt wird. Dasselbe geschieht auch bei einem andern Aufsatz uber denselben Gegenstand im 27. Bande oder neue Folge 15. Band p. 121, woselbst die durch Ludwig Foltz im Journ. f. Orn. (XII. p. 52) publicirten Beobachtungen über das Gefangenleben etc. fast wörtlich wiedergegeben werden.

Der Herr Mitarbeiter für "Aus der Natur" schöpft viel und mit Vorliebe aus dem Journal für Ornithologie, wolle er dabei die grosse Freundlichkeit haben, ferner nicht blos den Stoff, sondern auch den Autor za nennen.

Glog a u, den 12. Juli 1865. Alexander von Homeger.

\section{An die Redaction eingegangene Schriften.}

(Siehe Jnli-Heft 1865, s. 224.)

579. Storia naturale degli Uccelli che Nidificano in Lombardia od illustrazione della ruccolta ornithologica dei Fratelli Ercole ed Ernesto Turati scritta da Eugenio Bettoni, con'Tavole lithografate e colorate prese dal vero da 0 . Dressler. Vol. I., Fasc. I., [2 Tafeln and Text] fol. - Milano 1865. - Vom Grafen Dr. Ercole Turati.

580. The Ibis. A Quaterly Journal of Ornithology. New Series Vol. I. No. 2. April 1865. Edited by Alfred Newton. - Vom Herausgeber.

581. S. F. Baird. Review of American Birds, in the Yuseum of the Smithsonian Institution. Part I. North and Middle America. Pag. 209-320. Von der Smithsonian Institution durch Prof. Baird.

582. Geo. N. Lawrence. Descriptions of new Species of Birds of the Families $P$ aridae, Fireonidae, Tyrannidae and Trochilidae, with a note on Myiarchus panamensis. (Aus Proc. Acad. Nat. Sc. Philadelphia, 1865, p. 37-39.) - Vom Verfasser.

583. Geo. N. Lawrence. Descriptions of New Species of Birds of the Families Tanagridae, Dendrocolaptidae, Formicaridae, Tyrannidae and Trochilidae. (Reprinted trom the Annals of the Lyceum of Nat. Hist. in New-York, Vol. VIII, May 1865.) - Fon Demselben.

584. Dr. Ph. L. Sclater. List of a Collection of Birds from Huaheine, Society's Islands. (From Proc. Z. S. London, Jan. 12, 1864.) - On the Species of the Genus Chauna. - On some Additions of the Birds of the Falklands Islands. (Proc. Z. S. London, Febr. 23, 1864.) - On the Species of the American Genus Coccygus. (Proc. Z. S. London, March 8, 1864.) - Vom Verfasser.

585. Dr. Ph. L. Sclater and Osbert Salvin. Notes on a Collection of Birds from the Isthmus of Panama. (From Proc. Zool. Soc. London, June 28, 1864.) - Von Demselben.

586. Dr. Ph. L. Sclater. Description of a New Species of Duck from Madagascar. Cum Tab. XXXIV. [Anas Melleri.] (From. Proc. Zool. Soc. London, Novbr. 8, 1864.) - Von Demselben.

387. Dr. Ph. L. Sclater. Descriptions of Seven New Species of Birds discovered by the late Dr. John Natterer in Brazil. Uum Tabh. XXXVII, XXXVII, XXXIX. (From Proc. Z. S. London, Novbr. 22, 1864.) Von Demselben.

588. Dr. Ph. I. Sclater. Note on the Breeding of the Ground-Pegeon in the Society's Menagerie. (Proc. Z. S. London, Febr. 26, 1865.) - On a New Species of the Genus Basileuterus of Cabanis, with a Synopsis of the known Species of the Genus. Cum 'Tabb. LX, X. (Proc. Z. S. London, March 14, 1865.) - Description of a New Species of Passerine Bird from Madagascar [Hylophorba ruticilla nov. gen. et spec.] Cum T'ab. XIII. (From Proe. Z, S. London, March 28. 1865.) - Von Demselben. 